\title{
Comparative proteomic analysis identifies exosomal Eps8 protein as a potential metastatic biomarker for pancreatic cancer
}

\author{
KEIICHI OHSHIMA ${ }^{1}$, KEIICHI HATAKEYAMA ${ }^{1}$, KAORI KANTO ${ }^{1}$, TOMOMI IDE ${ }^{1}$, YUKO WATANABE ${ }^{1}$, \\ SACHI MOROMIZATO $^{1}$, KANAKO WAKABAYASHI-NAKAO ${ }^{1,3}$, NAOKI SAKURA ${ }^{1}$, \\ $\mathrm{KEN} \mathrm{YAMAGUCHI}^{2}$ and TOHRU MOCHIZUKI ${ }^{1}$ \\ ${ }^{1}$ Medical Genetics Division, Shizuoka Cancer Center Research Institute; \\ ${ }^{2}$ Shizuoka Cancer Center Hospital and Research Institute, Shizuoka 411-8777, Japan
}

Received June 12, 2018; Accepted November 1, 2018

DOI: $10.3892 /$ or.2018.6869

\begin{abstract}
Exosomes are small vesicles found in extracellular environments including blood, urine, and cell culture medium. Their contents are cell-type specific, and molecules embedded in exosomes can be useful fluid-based clinical biomarkers. To identify proteins with metastatic marker potential, we conducted a comparative exosomal proteome analysis using human pancreatic cancer cell lines derived from metastasis, ascites, and primary tumors. Metastatic potential of cell lines was assessed by migratory and invasive activities. A pancreatic cancer cell line from metastasis (SU.86.86) revealed 23-fold and 20-fold increases in cell migratory and invasive activities, respectively, compared to the MIA $\mathrm{PaCa}-2$ cell line derived from primary tumor cells. Liquid chromatography-mass spectrometry-based proteome analysis and subsequent validation by immunoblot analysis revealed that epidermal growth factor receptor pathway substrate 8 (Eps8) was highly abundant in exosomes from metastasis-derived SU.86.86 cells. Comparison of 12 pancreatic cancer cell lines derived from different stages of malignancy revealed a strong relationship between exosomal Eps 8 protein levels and cell motile activities (migration: $\mathrm{r}=0.85, \mathrm{P}=4.2 \times 10-4$; invasion: $\mathrm{r}=0.60$,
\end{abstract}

Correspondence to: Dr Keiichi Ohshima, Medical Genetics Division, Shizuoka Cancer Center Research Institute, 1007 Shimonagakubo, Nagaizumi-Cho, Sunto-Gun, Shizuoka 411-8777, Japan

E-mail: k.ohshima@scchr.jp

${ }^{3}$ Present address: Department of Pharmaceutical Sciences, International University of Health and Welfare, 2600-1 Kitakanemaru, Otawara, Tochigi 324-8501, Japan

Abbreviations: CM, culture medium; Ct, cycle threshold; EGF, epidermal growth factor; Eps8, epidermal growth factor receptor pathway substrate 8; FBS, fetal bovine serum; GAPDH, glyceraldehyde 3-phosphate dehydrogenase; LC-MS/MS, liquid chromatography-mass spectrometry; RTCA, real-time cell analysis; SDS-PAGE, SDS-polyacrylamide gel electrophoresis

Key words: Eps8, exosomes, pancreatic cancer, metastasis, pancreatic cancer cell line, proteomics, biomarker
$\mathrm{P}=3.2 \times 10-2)$. Conversely, relationships between intracellular Eps8 protein levels and cell motile activities were moderate (migration: $\mathrm{r}=0.65, \mathrm{P}=2.0 \times 10-2$; invasion: $\mathrm{r}=0.51, \mathrm{P}=9.2 \times 10-2$ ). It was therefore concluded that exosomal Eps8 protein levels were correlated with the migratory cell potential of human pancreatic cancer cells, indicating that exosomal Eps8 has the potential to be a metastatic biomarker for human pancreatic cancer.

\section{Introduction}

Exosomes are $30-100 \mathrm{~nm}$ membranous organelles that are released from cells into the extracellular microenvironment (1). Exosomes are vesicular carriers for intercellular communication, and they contain various signaling biomolecules, including proteins, metabolites, RNA, DNA, and lipids to target cells (2-4). Mass spectrometry and microarray technologies have been used to perform exosomal biomolecules profiling. These efforts have revealed that exosomal biomolecule composition varies depending on the cell type of origin $(1,5)$. Since exosomes are found in biological fluids, including blood and urine, exosomal biomolecules with disease specificity are promising targets in liquid biopsies (6).

Cancer diagnosis at an early stage, before it has grown and spread to other organs by metastasis, is a prerequisite for successful treatment. Pancreatic cancer is one of the most deadly cancer forms and the third leading cause of cancer-related deaths in the United States (7), the EU (8) and Japan (http://ganjoho. jp/en/professional/statistics/brochure/2017_en.html). Early stage pancreatic cancer is difficult to diagnose since it is asymptomatic, making pancreatic cancer particularly challenging to treat and/or cure (9). In most cases, pancreatic cancer growth and metastasis have occurred by the time of diagnosis, leading to the poorest outcomes among the major types of cancer with a 5-year survival rate of $<10 \%$ (7). While early diagnosis is essential for effective pancreatic cancer treatment and/or cure, there are currently no proven clinical tumor markers for the early stages of pancreatic cancer. However, recent developments in molecular profiling technologies have indicated that proteins and microRNAs identified in exosomes could be useful as fluid-based diagnostic and prognostic markers for pancreatic cancer $(10,11)$. 
Cell culture systems have been used for secretome analyses to identify the extracellular or exosomal proteins and microRNAs released into the medium (12-14). Using cancer cells coupled with proteomics- or transcriptomics-based approaches, we have identified an abundance of polyadenylate binding protein 1 and let-7 family microRNAs in exosomes isolated from metastatic duodenal cancer cells $(15,16)$. In the present study, we aimed to identify pancreatic cancer metastasis. We performed exosomal proteome analysis using pancreatic cancer cell lines derived from early (primary tumors), and late stages (ascites, and metastatic tumors) of tumor progression. Comparative analyses revealed that epidermal growth factor receptor pathway substrate 8 (Eps8) protein was abundant in exosomes derived from metastatic tumors and ascites and that the amount of exosomal Eps8 was quantitatively correlated with the in vitro cell migratory activity. These observations indicating that exosomal Eps8 is a predictive biomarker for pancreatic cancer metastasis.

\section{Materials and methods}

Cell culture. Cell lines used in the present study are listed in Table I. Cells were maintained in a humidified atmosphere $\left(37^{\circ} \mathrm{C}, 5 \% \mathrm{CO}_{2}\right)$ in RPMI-1640 medium (Sigma-Aldrich; Merck KGaA, Darmstadt, Germany) supplemented with 2 mM L-glutamine (Nissui Pharmaceutical, Co., Ltd., Tokyo, Japan), $100 \mathrm{U} / \mathrm{ml}$ penicillin- $100 \mathrm{mg} / \mathrm{ml}$ streptomycin, and $10 \%$ heat-inactivated (FBS) (all from Thermo Fisher Scientific, Inc., Waltham, MA, USA).

Cell migration and invasion assays. Real-time cell analysis (RTCA) of in vitro cell migratory and invasive activities was performed using an xCELLigence RTCA DP instrument (Roche Diagnostics, Indianapolis, IN, USA) as previously described (15). Samples were analyzed in quadruplicate as technical replicates. Data analysis was performed using the RTCA software (version 1.2) supplied with the instrument.

Production and isolation of exosomes. Exosomes were isolated from the cell culture medium as previously described $(15,16)$. Briefly, cells were cultured for $48 \mathrm{~h}$ at $37^{\circ} \mathrm{C}$ with $5 \% \mathrm{CO}_{2}$ in complete RPMI-1640 medium containing 10\% FBS depleted of contaminating microvesicles by centrifugation at $100,000 \mathrm{x} \mathrm{g}$ for $18 \mathrm{~h}$. Culture medium (CM) was collected and centrifuged at $800 \times \mathrm{g}$ for $5 \mathrm{~min}$ and at an additional $2,000 \mathrm{x} \mathrm{g}$ for $10 \mathrm{~min}$ to remove detached cells. The supernatant was then filtered through a $0.1-\mu \mathrm{m}$ pore polyethersulfone membrane filter (Thermo Fisher Scientific, Inc.) to remove cell debris and large vesicles, then concentrated using a Centricon Plus-70 with a 100,000-MW cut-off membrane (EMD Millipore; Billerica, MA, USA). Concentrated CM was ultracentrifuged at $100,000 \mathrm{x}$ g for $2 \mathrm{~h}$ at $4^{\circ} \mathrm{C}$ using a $70 \mathrm{Ti}$ rotor (Beckman Coulter, Inc., Brea, CA, USA). Resultant pellets were resuspended in $6 \mathrm{ml}$ phosphate-buffered saline (PBS) and ultracentrifuged at $100,000 \mathrm{x}$ f for $1 \mathrm{~h}$ at $4^{\circ} \mathrm{C}$ using a 100Ti rotor (Beckman Coulter, Inc.).

Proteome analysis using mass spectrometry. Exosomal proteome analysis was performed by LC-MS/MS (liquid chromatography-mass spectrometry) as previously described $(15,17)$.
Proteins $(200 \mu \mathrm{g})$ from isolated exosomes were dissolved in lysis buffer containing $7.5 \mathrm{M}$ urea and $2.5 \mathrm{M}$ thiourea (both from Sigma-Aldrich; Merck KGaA), $12.5 \%$ glycerol (Chemical Industries, Osaka, Japan), $50 \mathrm{mM}$ Tris, $2.5 \%$ n-octyl- $\beta$-D-glucoside, $6.25 \mathrm{mM}$ Tris(2-carboxyethyl) phosphine hydrochloride, and $1.25 \mathrm{mM}$ protease inhibitor (all from Sigma-Aldrich; Merck KGaA) before being rotated at $4^{\circ} \mathrm{C}$ for $60 \mathrm{~min}$. After centrifugation at $14,000 \mathrm{x}$ g for $60 \mathrm{~min}$ at $4^{\circ} \mathrm{C}$, the supernatant was fractionated using the Agilent 1200 HPLC system (Agilent Technologies, Inc., Santa Clara, CA, USA) with an Intrada WP-RP column $(0.46 \times 25 \mathrm{~cm}, 3-\mu \mathrm{m}$ particle size and 30-nm pore size; Imtakt, Kyoto, Japan). Collected fractions were digested with trypsin (Promega Corp., Madison, WI, USA) and analyzed by LC-MS/MS using a nanoflow LC-ESI linear ion trap-TOF NanoFrontier L mass spectrometer (Hitachi High-Technologies, Tokyo, Japan). Raw LC-ESI data were converted to peak list files using NanoFrontier L Data Processing software (Hitachi High-Technologies). The peak list files were used for protein identification with the MASCOT MS/MS ion search (http://www.matrixscience. com) and X! Tandem software (http://www.thegpm.org). Upon peptide sequence annotation, the UniProtKB/Swiss-Prot database (version 2016_10; Homo sapiens; http://www.uniprot. org/statistics/Swiss-Prot) was used with the following parameters: enzyme, trypsin or none (when used with the home-made dataset only); maximum number of missed cleavage, 1 ; peptide tolerance, 0.2 Da; MS/MS tolerance, $0.2 \mathrm{Da}$; variable modification, oxidation of methionine; and peptide charge, $(1+$, $2+$ and $3+$ ). All identified proteins with MASCOT threshold scores $<95 \%$ confidence level and peptide numbers $<2$ were then removed from the protein list using Scaffold software (http://www.proteomesoftware.com/products/scaffold/).

Immunoblot analysis. Exosomes and cells were lysed with 7.5 M urea-based lysis buffer as described above. Protein concentrations were determined by the Bradford assay (Bio-Rad Laboratories, Inc., Hercules, CA, USA). Proteins (5 or $10 \mu \mathrm{g}$ ) were subjected to $8 \%$ SDS-polyacrylamide gel electrophoresis (SDS-PAGE), and transferred onto an Immobilon-P polyvinylidene fluoride $(P V D F)$ membrane $(0.45-\mathrm{mm}$ pore size; EMD Millipore). PVDF membranes were blocked for $1 \mathrm{~h}$ at room temperature in Tris-buffered saline $(10 \mathrm{mM}$ Tris- $\mathrm{HCl}$, $\mathrm{pH} 7.5,150 \mathrm{mM} \mathrm{NaCl}$ ) containing $0.01 \%$ Tween-20 and 5\% non-fat dried milk (Wako Pure Chemical Industries). Blocked membranes were then incubated overnight at $4^{\circ} \mathrm{C}$ with primary monoclonal antibodies (listed in Table II). Membranes were then incubated for $1 \mathrm{~h}$ at room temperature with anti-mouse IgG antibodies conjugated with horseradish peroxidase (Table II). Specific proteins were visualized using an ECL Plus western blotting detection system (GE Healthcare, Wauwatosa, WI, USA) and a Fujifilm Luminescent Image Analyzer LAS3000 (Fujifilm, Tokyo, Japan). The molecular weight of each protein was deduced using Precision Plus Protein All Blue Standards (Bio-Rad Laboratories, Inc.).

RNA isolation and quantitative RT-PCR analysis. Cells were cultured for $48 \mathrm{~h}$, and total RNA was extracted using the miRNeasy Mini Kit (Qiagen, Hilden, Germany) as previously described (15). RNA samples were quantified with a NanoDrop spectrophotometer (Thermo Fisher Scientific, Inc.) and 


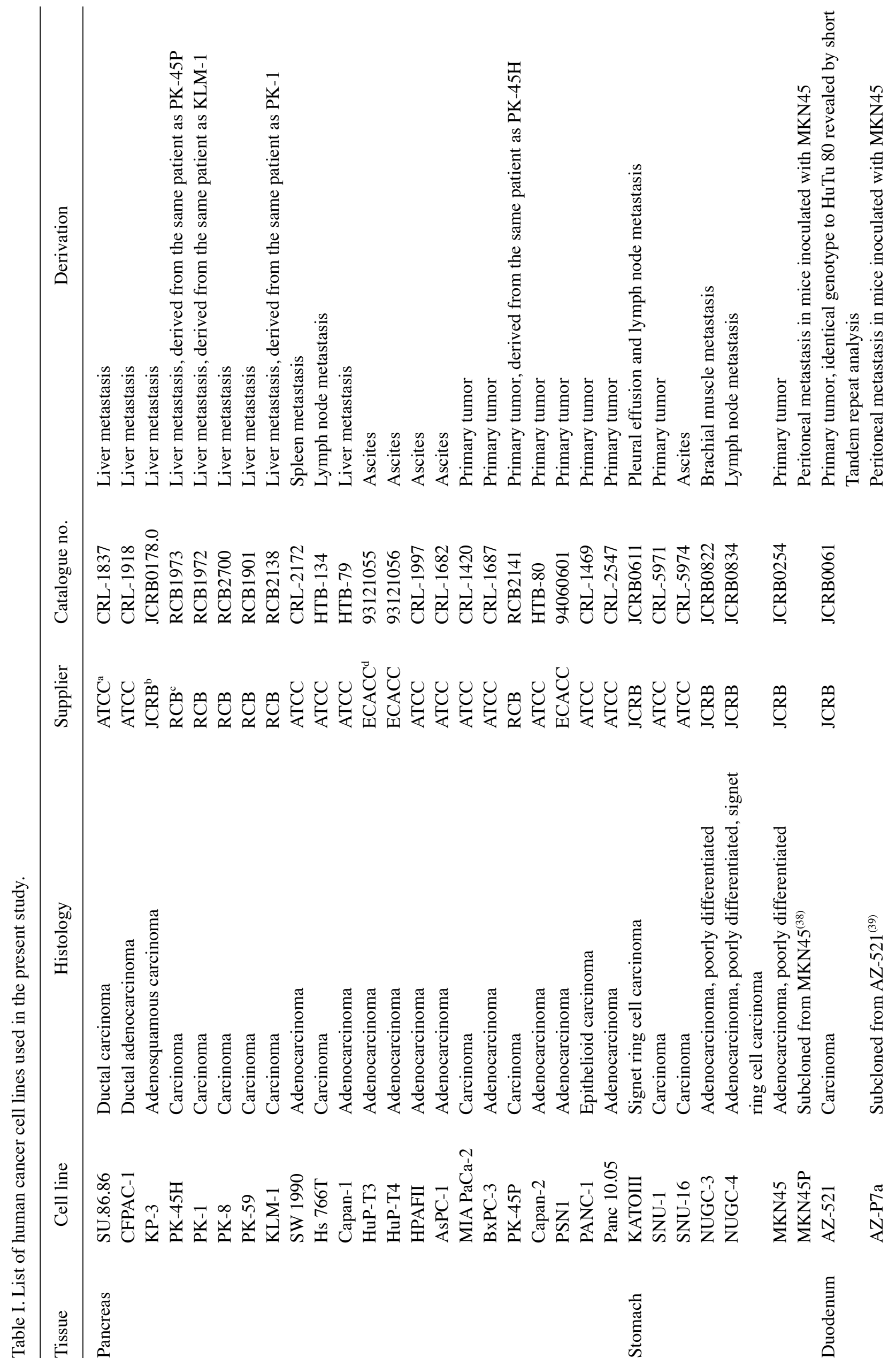




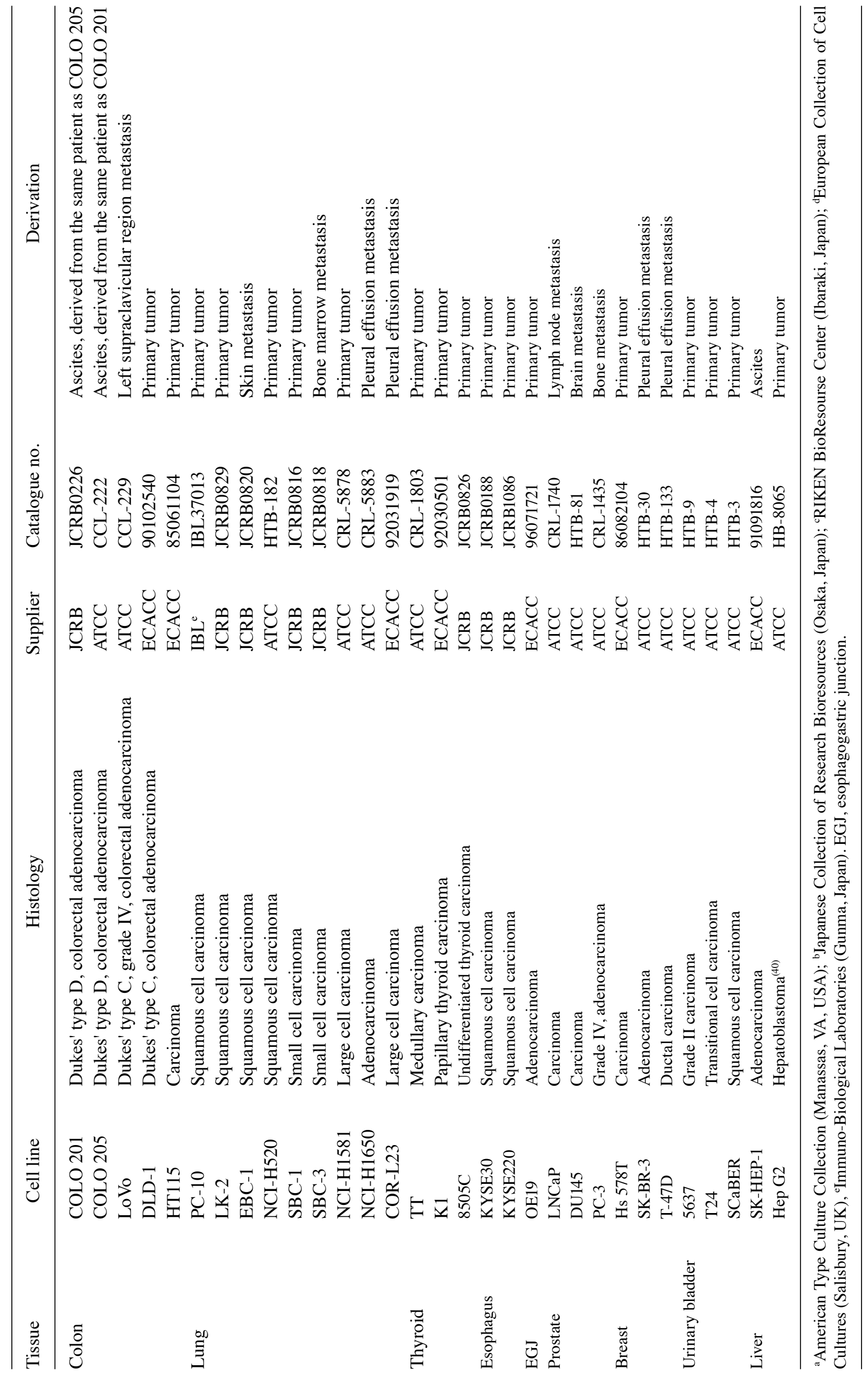


Table II. List of antibodies used for western blot analysis.

\begin{tabular}{lllllll}
\hline Protein & Clonality & Host & \multicolumn{1}{c}{ Supplier } & Catalogue no. & Dilution & Dilution of 2nd Ab \\
\hline Eps8 & Monoclonal & Mouse & BD Biosciences $^{\mathrm{a}}$ & 610144 & $1: 5,000$ & $1: 10,000^{\mathrm{d}}$ \\
$\alpha$-tubulin & Monoclonal & Mouse & EMD Millipore $^{\mathrm{b}}$ & CP06 & $1: 5,000$ & $1: 10,000^{\mathrm{d}}$ \\
GAPDH & Monoclonal & Mouse & SCBT $^{\mathrm{c}}$ & sc-36562 & $1: 1,000$ & $1: 5,000^{\mathrm{d}}$ \\
\hline
\end{tabular}

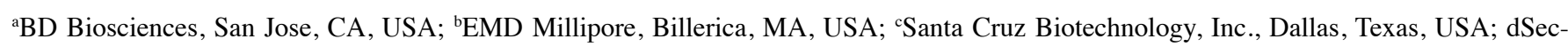
ondary antibody conjugated with horseradish peroxidase: Goat anti-mouse IgG antibody (cat. no. 115-035-062, Jackson ImmunoResearch Laboratories). Eps8, epidermal growth factor receptor pathway substrate 8; GAPDH, glyceraldehyde 3-phosphate dehydrogenase.

assessed using an Agilent 2100 Bioanalyzer and an RNA 6000 Nano Total RNA kit (both from Agilent Technologies, Inc.). Quantitative mRNA levels were determined using real-time RT-PCR using the Applied Biosystems 7900 HT Sequence Detection System, a TaqMan Gene Expression Assay for human EPS8 (assay ID Hs00610286_m1), and a Eukaryotic 18S rRNA Endogenous Control (Applied Biosystems; Thermo Fisher Scientific, Inc.). Only the probe sequence for EPS8 (TTGGATGAAAGCCAGAGCAGAGTGG) was provided by the manufacturer. The probes of EPS8 and 18S rRNA were labelled with FAM and VIC dyes, respectively. cDNA was generated using $100 \mathrm{ng}$ of total RNA, and a High Capacity cDNA Reverse Transcription kit (Applied Biosystems; Thermo Fisher Scientific, Inc.). RT-PCR was carried out in a total volume of $20 \mu 1$ containing $100 \mathrm{ng}$ of cDNA, TaqMan Fast Advanced Master Mix (Applied Biosystems), and the respective TaqMan target gene reagents. The amplification conditions were $95^{\circ} \mathrm{C}$ for $20 \mathrm{sec}$ followed by 40 cycles of $95^{\circ} \mathrm{C}$ for $1 \mathrm{sec}$ and $60^{\circ} \mathrm{C}$ for $20 \mathrm{sec}$. Samples were analyzed in triplicate as technical replicates. The EPS8 mRNA levels were defined from the cycle threshold $(\mathrm{Ct})$, using the comparative $\mathrm{Ct}$ method (18), and each sample was normalized by comparison to 18S rRNA levels. The fold change of EPS8 mRNA levels in each cell line was determined using SU.86.86 cell EPS8 mRNA levels as a reference.

Statistical analysis. Student's t-test for comparison of cell motility between SU.86.86 and MIA PaCa-2 cell lines, the Pearson correlation coefficient to compare two variables in five analyses (exosomal Eps8 protein, intracellular Eps8 protein, intracellular Eps8 mRNA, migration, and invasion), and Multiple t-tests with Bonferroni-correction for comparison of three different cell origins of metastasis, ascites and primary tumors were used. P-values $<0.05$ were considered to indicate a statistically significant difference.

\section{Results}

In vitro migratory and invasive activities of SU.86.86 and MIA PaCa-2 cells. SU.86.86 cells were derived from a liver metastasis of a pancreatic ductal carcinoma (19). MIA PaCa-2 cells were derived from a primary pancreatic adenocarcinoma (20). Before proteome analysis, we first performed in vitro cell migration and invasion assays to evaluate if the two cell lines exhibited differences in metastatic-potential. The impedance-based RTCA has shown a strong correlation
A
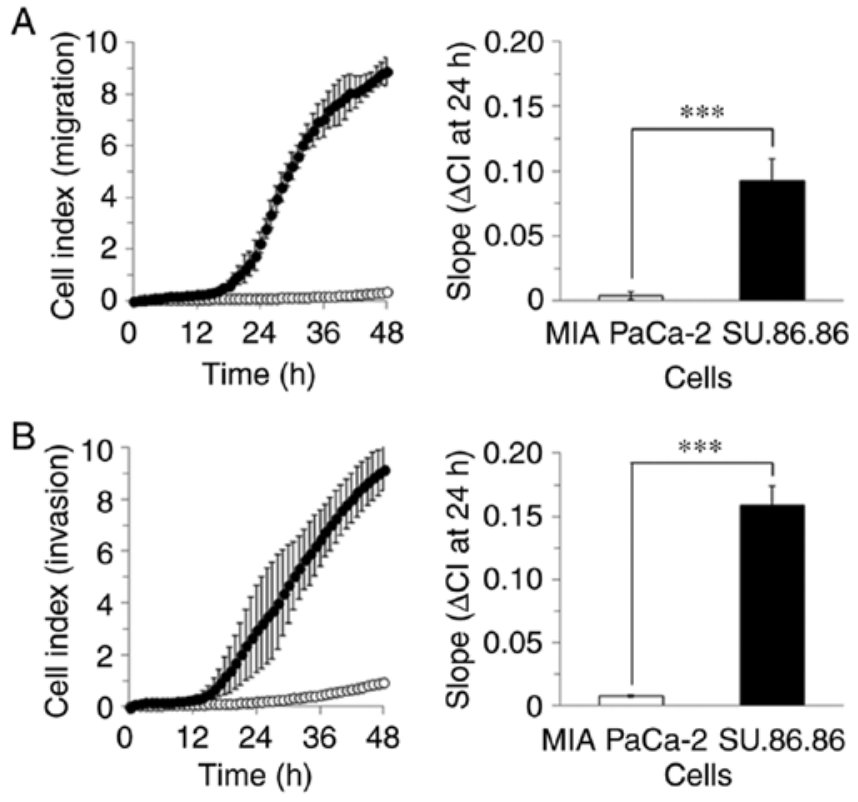

Figure 1. Real-time assessment of cell migration and invasion in human pancreatic cancer cell lines. Measurements were obtained for the metastasis-derived SU.86.86 and primary tumor-derived MIA PaCa-2 cell lines, using the xCELLigence RTCA DP instrument. Patterns of (A) cell migration and (B) invasion for SU.86.86 (closed circles) and MIA PaCa-2 (open circles) were reconstructed from the original data points by plotting data every hour. All data points are presented as the mean \pm SD from independent quadruplicate $(n=4)$ experiments. The kinetics for cell migration and invasion is presented as a linear slope of the cell index after $24 \mathrm{~h}$. Statistical significance $\left({ }^{* * *} \mathrm{P}<0.001\right)$ was evaluated using the Student's t-test.

with the conventional Boyden chamber Transwell endpoint assay $(15,21)$. Using the RTCA assay system, SU.86.86 cells had 23-fold greater cell migratory activity than did MIA PaCa-2 cells (Fig. 1A). Additionally, using a Matrigel barrier, SU.86.86 cells were found to be 20-times more invasive than MIA PaCa-2 cells (Fig. 1B). Collectively, these results indicated that the in vitro cell migratory and invasive behaviors of SU.86.86 and MIA PaCa-2 cells were correlated with their metastatic and primary tumor cell origins, respectively.

Exosomal proteome profiles of SU.86.86 and MIA PaCa-2 cells. The proteome profiles of SU.86.86 and MIA PaCa-2 cell-derived exosomes were analyzed using LC-MS/MS. After $48 \mathrm{~h}$ of cell growth, exosomes were isolated from culture media by a series of filtration and ultracentrifugation steps as previ- 
A

1. Comparative exosomal proteome analysis between human metastatic and primary pancreatic cancer cell lines, SU.86.86 and MIA PaCa-2, respectively

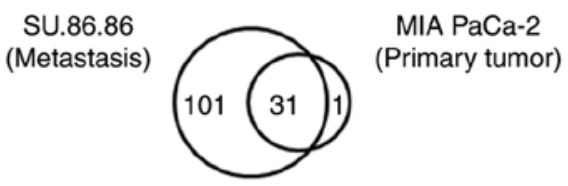

2. Comparison of 101 proteins specific to SU.86.86 exosomes with previously identified exosomal proteins from duodenal cancer cell lines AZ-521 and AZ-P7a

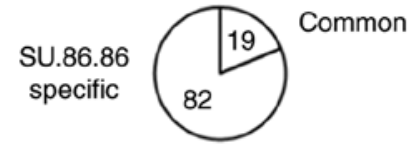

3. Selection of Eps8 from 82 proteins specific to SU.86.86 exosomes in the following conditions:

1) 2nd highest number of matched peptides (14)

2) 10th highest sequence coverage (29\%)

3) 6th highest total spectral count (32)
B

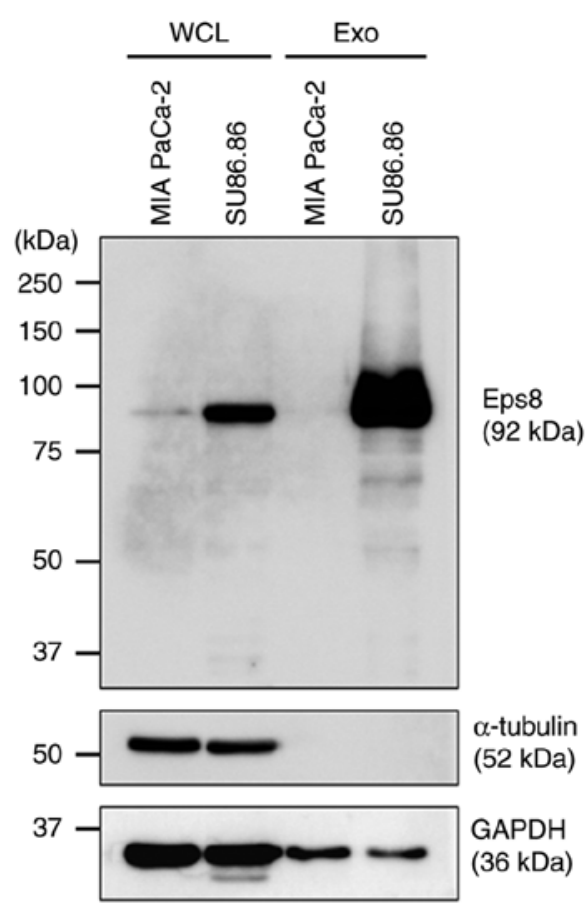

Figure 2. Identification of Eps8 in exosomes from SU.86.86 human metastatic pancreatic cancer cells by comparative proteomics. (A) The procedure was used to identify exosomal proteins specific to SU.86.86 cells. Comparison of proteins identified in SU.86.86-derived and MIA PaCa-2-derived exosomes revealed that 101 proteins were specifically observed in SU.86.86-derived exosomes (Venn diagram, step 1). All exosomal proteins derived from these two cell lines are listed in Table III. Comparison with proteins that had been previously identified in exosomes derived from duodenal cancer cell lines, AZ-521 and AZ-P7a (15) revealed that 82 from the 101 proteins aforementioned were specific to SU.86.86-derived exosomes (Pie chart, step 2). Comparative exosomal proteome data from the four cell lines are listed in Table IV. The Eps8 protein was selected as a specific exosomal protein derived from SU.86.86 in the indicated conditions (step 3). (B) Intracellular and exosomal Eps8 levels of SU.86.86 and MIA PaCa-2 cells. Proteins (10 mg) from WCL and Exo were separated by $8 \%$ SDS-PAGE and subjected to immunoblotting using antibodies against Eps8, $\alpha$-tubulin, and GAPDH, the latter two of which were used as internal standards for WCL. For Exo, these two housekeeping proteins, $\alpha$-tubulin and GAPDH, were not suitable for normalization (15), and no internal standard proteins were available. ESP8, epidermal growth factor receptor pathway substrate 8; WLC, whole cell lysates; Exo, exosomes.

ously described $(15,16)$. Proteome data processing identified a total of 133 proteins from exosomes derived from both cell lines (Fig. 2A, Table III). Among them, 31 proteins were identified in the exosomes of both cell types. A total of 101 proteins were uniquely identified in SU.86.86 cell-derived exosomes, and a single unique protein, histone $\mathrm{H} 2 \mathrm{~A}$ type 2-B (H2A2B), was identified in MIA PaCa-2 cell-derived exosomes.

Identification of Eps8 in SU.86.86 cell-derived exosomes. To identify the SU.86.86 cell-specific exosomal proteins, we compared the 101 SU.86.86 cell-specific proteins with those that had been previously identified in exosomes derived from human duodenal cancer cell lines AZ-521 and AZ-P7a (Fig. 2A) (15). This comparison identified 82 proteins that were unique to SU.86.86 cell-derived exosomes (Table IV). Of the 82 proteins unique to SU.86.86, Eps8 revealed relatively high MS/MS values, including the number of matched peptides, the rate of sequence coverage, and the total spectral count. Furthermore, the Eps8 expression was elevated in pancreatic cancer cells derived from ascites and metastasis (22). Therefore, we chose to validate the presence of Eps8 in exosomes by western blot analysis.

Western blot analyses revealed that the Eps8 protein was abundant in SU.86.86 cell-derived exosomes, while no immunoreactive Eps8 signals were detected in MIA PaCa-2 cell-derived exosomes (Fig. 2B). Furthermore, intracellular Eps8 expression levels were much higher in SU.86.86 cells than in MIA PaCa-2 cells, indicating a positive correlation with tumor malignancy, as previously reported (22). Comparison of the house-keeping proteins in the exosomes of both cell types revealed variation in glyceraldehyde 3-phosphate dehydrogenase (GAPDH) levels and no immunoreactive signals for $\alpha$-tubulin, making them unsuitable for normalizing exosomal protein levels previously described (15).

Exosomal Eps8 is abundant in metastasis- and ascites-derived pancreatic cancer cells. Eps8 was specifically detected in exosomes from metastatic-derived SU.86.86 cells. Therefore, we assessed exosomal Eps8 protein levels in other pancreatic cancer cell lines. Western blot analysis revealed positive immunoreactive Eps8 signals in exosomes from metastasis-derived pancreatic cancer cell lines, including CFPAC-1, KP-3, PK-45H, PK-8 and Capan-1 (Fig. 3A). Additionally, positive immunoreactive Eps8 signals were observed in exosomes from ascites-derived pancreatic cancer cell lines, including HuP-T3, HuP-T4 and AsPC-1. In contrast, Capan-2 was the only primary tumor cell line that exhibited Eps8 immunoreactivity. Densitometric analysis, using relative amounts of exosomal Eps8 protein, was used to quantify the Eps8 immunoreactivities observed (Fig. 4). The level of Eps8 immunoreactivity in the exosomes of different cell lines was assessed relative to that observed in SU.86.86 cell-derived exosomes, which was given a value of 1.0. The relative Eps8 immunoreactivity was $0.76,0.15$ and 0.17 in metastatic cell lines PK-45H, CFPAC-1 
Table III. List of proteins identified in exosomes derived from SU.86.86 and MIA PaCa-2 cells.

\begin{tabular}{|c|c|c|c|c|c|}
\hline \multirow[b]{2}{*}{ Accession no. } & \multirow{2}{*}{$\begin{array}{l}\text { UniProtKB/Swiss-Prot } \\
\text { entry name }\end{array}$} & \multirow[b]{2}{*}{ Protein name } & \multirow[b]{2}{*}{ M.W. (kDa) } & \multicolumn{2}{|c|}{$\begin{array}{l}\text { Number of } \\
\text { matched peptides }\end{array}$} \\
\hline & & & & SU.86.86 & MIA PaCa-2 \\
\hline Q7Z406 & MYH14_HUMAN & Myosin-14 & 228 & 29 & 0 \\
\hline Q12929 & EPS8_HUMAN & $\begin{array}{l}\text { Epidermal growth factor receptor } \\
\text { pathway substrate } 8\end{array}$ & 92 & 14 & 0 \\
\hline Q14764 & MVP_HUMAN & Major vault protein & 99 & 14 & 0 \\
\hline P05121 & PAI1_HUMAN & Plasminogen activator inhibitor 1 & 45 & 10 & 0 \\
\hline P16104 & H2AX_HUMAN & Histone $\mathrm{H} 2 \mathrm{AX}$ & 15 & 8 & 0 \\
\hline P21589 & 5NTD_HUMAN & 5'-nucleotidase & 63 & 7 & 0 \\
\hline P84243 & H33_HUMAN & Histone H3.3 & 15 & 7 & 0 \\
\hline Q9GZM7 & TINAL_HUMAN & $\begin{array}{l}\text { Tubulointerstitial nephritis } \\
\text { antigen-like }\end{array}$ & 52 & 7 & 0 \\
\hline P01023 & A2MG_HUMAN & Alpha-2-macroglobulin & 163 & 6 & 0 \\
\hline P80188 & NGAL_HUMAN & $\begin{array}{l}\text { Neutrophil gelatinase-associated } \\
\text { lipocalin }\end{array}$ & 23 & 6 & 0 \\
\hline P23396 & RS3_HUMAN & 40S ribosomal protein $\mathrm{S} 3$ & 27 & 5 & 0 \\
\hline Q9UQB8 & BAIP2_HUMAN & $\begin{array}{l}\text { Brain-specific angiogenesis inhibitor } \\
\text { 1-associated protein } 2\end{array}$ & 61 & 5 & 0 \\
\hline Q9UHR4 & BI2L1_HUMAN & $\begin{array}{l}\text { Brain-specific angiogenesis inhibitor } \\
1 \text {-associated protein } 2 \text {-like protein } 1\end{array}$ & 57 & 5 & 0 \\
\hline P02458 & CO2A1_HUMAN & Collagen alpha-1 (II) chain & 142 & 5 & 0 \\
\hline P23142 & FBLN1_HUMAN & Fibulin-1 & 77 & 5 & 0 \\
\hline P13647 & K2C5_HUMAN & Keratin, type II cytoskeletal 5 & 62 & 5 & 0 \\
\hline P05787 & K2C8_HUMAN & Keratin, type II cytoskeletal 8 & 54 & 5 & 0 \\
\hline P15880 & RS2_HUMAN & $40 \mathrm{~S}$ ribosomal protein $\mathrm{S} 2$ & 31 & 4 & 0 \\
\hline P08865 & RSSA_HUMAN & 40S ribosomal protein $\mathrm{SA}$ & 33 & 4 & 0 \\
\hline P09525 & ANXA4_HUMAN & Annexin A4 & 36 & 4 & 0 \\
\hline P08133 & ANXA6_HUMAN & Annexin A6 & 76 & 4 & 0 \\
\hline O95994 & AGR2_HUMAN & Anterior gradient protein 2 homolog & 20 & 4 & 0 \\
\hline O15335 & CHAD_HUMAN & Chondroadherin & 40 & 4 & 0 \\
\hline P12109 & CO6A1_HUMAN & Collagen alpha-1 (VI) chain & 109 & 4 & 0 \\
\hline P39060 & COIA1_HUMAN & Collagen alpha-1 (XVIII) chain & 178 & 4 & 0 \\
\hline P08238 & HS90B_HUMAN & Heat shock protein HSP 90-beta & 83 & 4 & 0 \\
\hline Q16270 & IBP7_HUMAN & $\begin{array}{l}\text { Insulin-like growth factor-binding } \\
\text { protein } 7\end{array}$ & 29 & 4 & 0 \\
\hline Q08431 & MFGM_HUMAN & Lactadherin & 43 & 4 & 0 \\
\hline Q13753 & LAMC2_HUMAN & Laminin subunit gamma-2 & 131 & 4 & 0 \\
\hline Q9NRN5 & OLFL3_HUMAN & Olfactomedin-like protein 3 & 46 & 4 & 0 \\
\hline O00391 & QSOX1_HUMAN & Sulfhydryl oxidase 1 & 83 & 4 & 0 \\
\hline P00750 & TPA_HUMAN & Tissue-type plasminogen activator & 63 & 4 & 0 \\
\hline P29144 & TPP2_HUMAN & Tripeptidyl-peptidase 2 & 138 & 4 & 0 \\
\hline Q9H9H4 & VP37B_HUMAN & $\begin{array}{l}\text { Vacuolar protein sorting-associated } \\
\text { protein } 37 \mathrm{~B}\end{array}$ & 31 & 4 & 0 \\
\hline P62241 & RS8_HUMAN & 40S ribosomal protein $\mathrm{S} 8$ & 24 & 3 & 0 \\
\hline P46781 & RS9_HUMAN & 40S ribosomal protein $\mathrm{S} 9$ & 23 & 3 & 0 \\
\hline Q07020 & RL18_HUMAN & $60 S$ ribosomal protein L18 & 22 & 3 & 0 \\
\hline P12429 & ANXA3_HUMAN & Annexin A3 & 36 & 3 & 0 \\
\hline O75531 & BAF_HUMAN & Barrier-to-autointegration factor & 10 & 3 & 0 \\
\hline P02462 & CO4A1_HUMAN & Collagen alpha-1(IV) chain & 161 & 3 & 0 \\
\hline Q86YQ8 & CPNE8_HUMAN & Copine- 8 & 63 & 3 & 0 \\
\hline
\end{tabular}


Table III. Continued.

\begin{tabular}{|c|c|c|c|c|c|}
\hline \multirow[b]{2}{*}{ Accession no. } & \multirow{2}{*}{$\begin{array}{l}\text { UniProtKB/Swiss-Prot } \\
\text { entry name }\end{array}$} & \multirow[b]{2}{*}{ Protein name } & \multirow[b]{2}{*}{ M.W. (kDa) } & \multicolumn{2}{|c|}{$\begin{array}{l}\text { Number of } \\
\text { matched peptides }\end{array}$} \\
\hline & & & & SU.86.86 & MIA PaCa-2 \\
\hline P68871 & HBB_HUMAN & Hemoglobin subunit beta & 16 & 3 & 0 \\
\hline P16403 & H12_HUMAN & Histone H1.2 & 21 & 3 & 0 \\
\hline Q71UI9 & H2AV_HUMAN & Histone H2A.V & 14 & 3 & 0 \\
\hline Q6ZNF0 & ACP7_HUMAN & Acid phosphatase type 7 & 50 & 3 & 0 \\
\hline $\mathrm{P} 02533$ & K1C14_HUMAN & Keratin, type I cytoskeletal 14 & 52 & 3 & 0 \\
\hline P05783 & K1C18_HUMAN & Keratin, type I cytoskeletal 18 & 48 & 3 & 0 \\
\hline P04259 & K2C6B_HUMAN & Keratin, type II cytoskeletal 6B & 60 & 3 & 0 \\
\hline Q16787 & LAMA3_HUMAN & Laminin subunit alpha-3 & 367 & 3 & 0 \\
\hline P60660 & MYL6_HUMAN & Myosin light polypeptide 6 & 17 & 3 & 0 \\
\hline P19105 & ML12A_HUMAN & Myosin regulatory light chain $12 \mathrm{~A}$ & 20 & 3 & 0 \\
\hline P19338 & NUCL_HUMAN & Nucleolin & 77 & 3 & 0 \\
\hline Q8WUM4 & PDC6I_HUMAN & $\begin{array}{l}\text { Programmed cell death 6-interacting } \\
\text { protein }\end{array}$ & 96 & 3 & 0 \\
\hline P00734 & THRB_HUMAN & Prothrombin & 70 & 3 & 0 \\
\hline P78371 & TCPB_HUMAN & T-complex protein 1 subunit beta & 57 & 3 & 0 \\
\hline P68371 & TBB4B_HUMAN & Tubulin beta-4B chain & 50 & 3 & 0 \\
\hline P62195 & PRS8_HUMAN & $26 \mathrm{~S}$ protease regulatory subunit 8 & 46 & 2 & 0 \\
\hline P62847 & RS24_HUMAN & 40S ribosomal protein $S 24$ & 15 & 2 & 0 \\
\hline P50914 & RL14_HUMAN & $60 S$ ribosomal protein L14 & 23 & 2 & 0 \\
\hline P61313 & RL15_HUMAN & $60 \mathrm{~S}$ ribosomal protein L15 & 24 & 2 & 0 \\
\hline P18124 & RL7_HUMAN & $60 \mathrm{~S}$ ribosomal protein $\mathrm{L} 7$ & 29 & 2 & 0 \\
\hline P62424 & RL7A_HUMAN & $60 \mathrm{~S}$ ribosomal protein $\mathrm{L} 7 \mathrm{a}$ & 30 & 2 & 0 \\
\hline P53999 & TCP4_HUMAN & $\begin{array}{l}\text { Activated RNA polymerase II } \\
\text { transcriptional coactivator p15 }\end{array}$ & 14 & 2 & 0 \\
\hline P08758 & ANXA5_HUMAN & Annexin A5 & 36 & 2 & 0 \\
\hline P98160 & PGBM_HUMAN & $\begin{array}{l}\text { Basement membrane-specific heparan } \\
\text { sulfate proteoglycan core protein }\end{array}$ & 469 & 2 & 0 \\
\hline P02749 & APOH_HUMAN & Beta-2-glycoprotein 1 & 38 & 2 & 0 \\
\hline P62158 & CALM_HUMAN & Calmodulin & 17 & 2 & 0 \\
\hline P15169 & CBPN_HUMAN & Carboxypeptidase $\mathrm{N}$ catalytic chain & 52 & 2 & 0 \\
\hline P49747 & COMP_HUMAN & Cartilage oligomeric matrix protein & 83 & 2 & 0 \\
\hline Q9NZZ3 & CHMP5_HUMAN & Charged multivesicular body protein 5 & 25 & 2 & 0 \\
\hline P08123 & CO1A2_HUMAN & Collagen alpha-2(I) chain & 129 & 2 & 0 \\
\hline P01031 & CO5_HUMAN & Complement C5 & 188 & 2 & 0 \\
\hline O75367 & H2AY_HUMAN & Core histone macro-H2A.1 & 40 & 2 & 0 \\
\hline P26641 & EF1G_HUMAN & Elongation factor 1-gamma & 50 & 2 & 0 \\
\hline Q9H6S3 & ES8L2_HUMAN & $\begin{array}{l}\text { Epidermal growth factor receptor kinase } \\
\text { substrate } 8 \text {-like protein } 2\end{array}$ & 81 & 2 & 0 \\
\hline P09972 & ALDOC_HUMAN & Fructose-bisphosphate aldolase C & 39 & 2 & 0 \\
\hline P23229 & ITA6_HUMAN & Integrin alpha-6 & 127 & 2 & 0 \\
\hline Q7Z794 & K2C1B_HUMAN & Keratin, type II cytoskeletal 1b & 62 & 2 & 0 \\
\hline P19013 & K2C4_HUMAN & Keratin, type II cytoskeletal 4 & 57 & 2 & 0 \\
\hline $\mathrm{P} 02538$ & K2C6A_HUMAN & Keratin, type II cytoskeletal 6A & 60 & 2 & 0 \\
\hline P08729 & K2C7_HUMAN & Keratin, type II cytoskeletal 7 & 51 & 2 & 0 \\
\hline P51884 & LUM_HUMAN & Lumican & 38 & 2 & 0 \\
\hline Q14112 & NID2_HUMAN & Nidogen-2 & 151 & 2 & 0 \\
\hline P30101 & PDIA3_HUMAN & Protein disulfide-isomerase A3 & 57 & 2 & 0 \\
\hline P60903 & S10AA_HUMAN & Protein S100-A10 & 11 & 2 & 0 \\
\hline P31949 & S10AB_HUMAN & Protein S100-A11 & 12 & 2 & 0 \\
\hline
\end{tabular}


Table III. Continued.

\begin{tabular}{|c|c|c|c|c|c|}
\hline \multirow[b]{2}{*}{ Accession no. } & \multirow{2}{*}{$\begin{array}{c}\text { UniProtKB/Swiss-Prot } \\
\text { entry name }\end{array}$} & \multirow[b]{2}{*}{ Protein name } & \multirow[b]{2}{*}{ M.W. (kDa) } & \multicolumn{2}{|c|}{$\begin{array}{l}\text { Number of } \\
\text { matched peptides }\end{array}$} \\
\hline & & & & SU.86.86 & MIA PaCa-2 \\
\hline P21980 & TGM2_HUMAN & Protein-glutamine gamma-glutamyltransferase 2 & 77 & 2 & 0 \\
\hline Q92954 & PRG4_HUMAN & Proteoglycan 4 & 151 & 2 & 0 \\
\hline P50454 & SERPH_HUMAN & Serpin H1 & 46 & 2 & 0 \\
\hline P24821 & TENA_HUMAN & Tenascin & 241 & 2 & 0 \\
\hline P35908 & K22E_HUMAN & Keratin, type II cytoskeletal 2 epidermal & 65 & 16 & 1 \\
\hline P07437 & TBB5_HUMAN & Tubulin beta chain & 50 & 15 & 1 \\
\hline P0C0L4 & CO4A_HUMAN & Complement C4-A & 193 & 9 & 1 \\
\hline P35580 & MYH10_HUMAN & Myosin-10 & 229 & 9 & 1 \\
\hline P68363 & TBA1B_HUMAN & Tubulin alpha-1B chain & 50 & 7 & 1 \\
\hline P36955 & PEDF_HUMAN & Pigment epithelium-derived factor & 46 & 6 & 1 \\
\hline P16401 & H15_HUMAN & Histone H1.5 & 23 & 5 & 1 \\
\hline P23284 & PPIB_HUMAN & Peptidyl-prolyl cis-trans isomerase B & 24 & 5 & 1 \\
\hline Q9H444 & CHM4B_HUMAN & Charged multivesicular body protein $4 \mathrm{~b}$ & 25 & 4 & 1 \\
\hline P05452 & TETN_HUMAN & Tetranectin & 23 & 4 & 1 \\
\hline P62854 & RS26_HUMAN & $40 S$ ribosomal protein $S 26$ & 13 & 2 & 1 \\
\hline P35579 & MYH9_HUMAN & Myosin-9 & 227 & 78 & 11 \\
\hline $\mathrm{P} 02751$ & FINC_HUMAN & Fibronectin & 263 & 42 & 5 \\
\hline P04264 & K2C1_HUMAN & Keratin, type II cytoskeletal 1 & 66 & 29 & 9 \\
\hline P07996 & TSP1_HUMAN & Thrombospondin-1 & 129 & 27 & 2 \\
\hline P13645 & K1C10_HUMAN & Keratin, type I cytoskeletal 10 & 59 & 26 & 4 \\
\hline P35527 & K1C9_HUMAN & Keratin, type I cytoskeletal 9 & 62 & 19 & 2 \\
\hline P01024 & CO3_HUMAN & Complement C3 & 187 & 17 & 2 \\
\hline P60709 & ACTB_HUMAN & Actin, cytoplasmic 1 & 42 & 15 & 4 \\
\hline P07355 & ANXA2_HUMAN & Annexin A2 & 39 & 14 & 2 \\
\hline P11142 & HSP7C_HUMAN & Heat shock cognate $71 \mathrm{kDa}$ protein & 71 & 13 & 13 \\
\hline P15311 & EZRI_HUMAN & Ezrin & 69 & 13 & 6 \\
\hline P62805 & H4_HUMAN & Histone H4 & 11 & 10 & 6 \\
\hline P04406 & G3P_HUMAN & Glyceraldehyde-3-phosphate dehydrogenase & 36 & 10 & 3 \\
\hline P06396 & GELS_HUMAN & Gelsolin & 86 & 10 & 2 \\
\hline P12259 & FA5_HUMAN & Coagulation factor $\mathrm{V}$ & 252 & 9 & 4 \\
\hline P14618 & KPYM_HUMAN & Pyruvate kinase PKM & 58 & 9 & 3 \\
\hline O00560 & SDCB1_HUMAN & Syntenin-1 & 32 & 9 & 2 \\
\hline P33778 & H2B1B_HUMAN & Histone $\mathrm{H} 2 \mathrm{~B}$ type $1-\mathrm{B}$ & 14 & 8 & 3 \\
\hline P04083 & ANXA1_HUMAN & Annexin A1 & 39 & 8 & 2 \\
\hline P69905 & HBA_HUMAN & Hemoglobin subunit alpha & 15 & 6 & 3 \\
\hline P02768 & ALBU_HUMAN & Serum albumin & 69 & 5 & 4 \\
\hline P68104 & EF1A1_HUMAN & Elongation factor 1-alpha 1 & 50 & 5 & 3 \\
\hline P04075 & ALDOA_HUMAN & Fructose-bisphosphate aldolase A & 39 & 5 & 3 \\
\hline P06733 & ENOA_HUMAN & Alpha-enolase & 47 & 4 & 2 \\
\hline P03956 & MMP1_HUMAN & Interstitial collagenase & 54 & 4 & 2 \\
\hline P02788 & TRFL_HUMAN & Lactotransferrin & 78 & 2 & 5 \\
\hline P62249 & RS16_HUMAN & $40 \mathrm{~S}$ ribosomal protein $\mathrm{S} 16$ & 16 & 2 & 4 \\
\hline P10643 & CO7_HUMAN & Complement component C7 & 94 & 2 & 3 \\
\hline P02748 & CO9_HUMAN & Complement component C9 & 63 & 2 & 3 \\
\hline Q71DI3 & H32_HUMAN & Histone H3.2 & 15 & 2 & 2 \\
\hline Q06830 & PRDX1_HUMAN & Peroxiredoxin-1 & 22 & 2 & 2 \\
\hline Q8IUE6 & H2A2B_HUMAN & Histone $\mathrm{H} 2 \mathrm{~A}$ type 2-B & 14 & 0 & 3 \\
\hline
\end{tabular}


Table IV. List of proteins specifically identified in exosomes derived from SU.86.86 compared to other cancer cell lines.

\begin{tabular}{|c|c|c|c|c|c|c|}
\hline Accession no. & $\begin{array}{l}\text { UniProtKB/Swiss-Prot } \\
\text { entry name }\end{array}$ & Protein name & $\begin{array}{l}\text { M.W. } \\
(\mathrm{kDa})\end{array}$ & $\begin{array}{l}\text { Number of } \\
\text { matched } \\
\text { peptides }\end{array}$ & $\begin{array}{c}\text { Sequence } \\
\text { coverage }(\%)\end{array}$ & $\begin{array}{l}\text { Total } \\
\text { spectral } \\
\text { count }\end{array}$ \\
\hline Q7Z406 & MYH14_HUMAN & Myosin-14 & 228 & 29 & 19 & 71 \\
\hline Q12929 & EPS8_HUMAN & $\begin{array}{l}\text { Epidermal growth factor receptor } \\
\text { pathway substrate } 8\end{array}$ & 92 & 14 & 29 & 32 \\
\hline Q14764 & MVP_HUMAN & Major vault protein & 99 & 14 & 25 & 27 \\
\hline P05121 & PAI1_HUMAN & Plasminogen activator inhibitor 1 & 45 & 10 & 31 & 28 \\
\hline P16104 & H2AX_HUMAN & Histone $\mathrm{H} 2 \mathrm{AX}$ & 15 & 8 & 52 & 46 \\
\hline P84243 & H33_HUMAN & Histone H3.3 & 15 & 7 & 52 & 28 \\
\hline Q9GZM7 & TINAL_HUMAN & $\begin{array}{l}\text { Tubulointerstitial nephritis } \\
\text { antigen-like }\end{array}$ & 52 & 7 & 21 & 18 \\
\hline P21589 & 5NTD_HUMAN & 5'-nucleotidase & 63 & 7 & 17 & 15 \\
\hline P80188 & NGAL_HUMAN & $\begin{array}{l}\text { Neutrophil gelatinase-associated } \\
\text { lipocalin }\end{array}$ & 23 & 6 & 44 & 24 \\
\hline P36955 & PEDF_HUMAN & $\begin{array}{l}\text { Pigment epithelium-derived } \\
\text { factor }\end{array}$ & 46 & 6 & 17 & 13 \\
\hline P23284 & PPIB_HUMAN & $\begin{array}{l}\text { Peptidyl-prolyl cis-trans } \\
\text { isomerase B }\end{array}$ & 24 & 5 & 29 & 14 \\
\hline P13647 & K2C5_HUMAN & Keratin, type II cytoskeletal 5 & 62 & 5 & 17 & 22 \\
\hline P05787 & K2C8_HUMAN & Keratin, type II cytoskeletal 8 & 54 & 5 & 16 & 15 \\
\hline P16401 & H15_HUMAN & Histone H1.5 & 23 & 5 & 16 & 13 \\
\hline Q9UQB8 & BAIP2_HUMAN & $\begin{array}{l}\text { Brain-specific angiogenesis } \\
\text { inhibitor 1-associated protein } 2\end{array}$ & 61 & 5 & 15 & 6 \\
\hline Q9UHR4 & BI2L1_HUMAN & $\begin{array}{l}\text { Brain-specific angiogenesis } \\
\text { inhibitor } 1 \text {-associated protein } \\
\text { 2-like protein } 1\end{array}$ & 57 & 5 & 14 & 16 \\
\hline P23142 & FBLN1_HUMAN & Fibulin-1 & 77 & 5 & 6 & 13 \\
\hline P02458 & CO2A1_HUMAN & Collagen alpha-1 (II) chain & 142 & 5 & 4 & 13 \\
\hline O95994 & AGR2_HUMAN & $\begin{array}{l}\text { Anterior gradient protein } 2 \\
\text { homolog }\end{array}$ & 20 & 4 & 30 & 5 \\
\hline Q9H444 & CHM4B_HUMAN & $\begin{array}{l}\text { Charged multivesicular body } \\
\text { protein } 4 \mathrm{~b}\end{array}$ & 25 & 4 & 22 & 7 \\
\hline Q9H9H4 & VP37B_HUMAN & $\begin{array}{l}\text { Vacuolar protein sorting- } \\
\text { associated protein } 37 \mathrm{~B}\end{array}$ & 31 & 4 & 22 & 4 \\
\hline P08865 & RSSA_HUMAN & 40S ribosomal protein SA & 33 & 4 & 21 & 6 \\
\hline O15335 & CHAD_HUMAN & Chondroadherin & 40 & 4 & 16 & 8 \\
\hline P09525 & ANXA4_HUMAN & Annexin A4 & 36 & 4 & 16 & 5 \\
\hline Q16270 & IBP7_HUMAN & $\begin{array}{l}\text { Insulin-like growth factor- } \\
\text { binding protein } 7\end{array}$ & 29 & 4 & 15 & 11 \\
\hline Q08431 & MFGM_HUMAN & Lactadherin & 43 & 4 & 13 & 4 \\
\hline P00750 & TPA_HUMAN & Tissue-type plasminogen activator & 63 & 4 & 11 & 8 \\
\hline P08133 & ANXA6_HUMAN & Annexin A6 & 76 & 4 & 9 & 4 \\
\hline O00391 & QSOX1_HUMAN & Sulfhydryl oxidase 1 & 83 & 4 & 6 & 7 \\
\hline P12109 & CO6A1_HUMAN & Collagen alpha-1 (VI) chain & 109 & 4 & 5 & 7 \\
\hline Q13753 & LAMC2_HUMAN & Laminin subunit gamma-2 & 131 & 4 & 5 & 8 \\
\hline P29144 & TPP2_HUMAN & Tripeptidyl-peptidase 2 & 138 & 4 & 5 & 4 \\
\hline P39060 & COIA1_HUMAN & Collagen alpha-1 (XVIII) chain & 178 & 4 & 4 & 6 \\
\hline O75531 & BAF_HUMAN & Barrier-to-autointegration factor & 10 & 3 & 43 & 5 \\
\hline P68371 & TBB4B_HUMAN & Tubulin beta-4B chain & 50 & 3 & 41 & 45 \\
\hline Q71UI9 & H2AV_HUMAN & Histone H2A.V & 14 & 3 & 31 & 25 \\
\hline P19105 & ML12A_HUMAN & Myosin regulatory light chain 12A & 20 & 3 & 27 & 3 \\
\hline P60660 & MYL6_HUMAN & Myosin light polypeptide 6 & 17 & 3 & 24 & 7 \\
\hline
\end{tabular}


Table IV. Continued.

\begin{tabular}{|c|c|c|c|c|c|c|}
\hline Accession no. & $\begin{array}{l}\text { UniProtKB/Swiss-Prot } \\
\text { entry name }\end{array}$ & Protein name & $\begin{array}{l}\text { M.W. } \\
\text { (kDa) }\end{array}$ & $\begin{array}{c}\text { Number of } \\
\text { matched } \\
\text { peptides }\end{array}$ & $\begin{array}{c}\text { Sequence } \\
\text { coverage }(\%)\end{array}$ & $\begin{array}{c}\text { Total } \\
\text { spectral } \\
\text { count }\end{array}$ \\
\hline P02533 & K1C14_HUMAN & Keratin, type I cytoskeletal 14 & 52 & 3 & 18 & 40 \\
\hline P12429 & ANXA3_HUMAN & Annexin A3 & 36 & 3 & 14 & 3 \\
\hline P05783 & K1C18_HUMAN & Keratin, type I cytoskeletal 18 & 48 & 3 & 13 & 7 \\
\hline P04259 & K2C6B_HUMAN & Keratin, type II cytoskeletal 6B & 60 & 3 & 12 & 38 \\
\hline P46781 & RS9_HUMAN & $40 \mathrm{~S}$ ribosomal protein $\mathrm{S} 9$ & 23 & 3 & 12 & 6 \\
\hline Q6ZNF0 & ACP7_HUMAN & Acid phosphatase type 7 & 50 & 3 & 12 & 5 \\
\hline P78371 & TCPB_HUMAN & T-complex protein 1 subunit beta & 57 & 3 & 11 & 3 \\
\hline Q86YQ8 & CPNE8_HUMAN & Copine-8 & 63 & 3 & 8 & 3 \\
\hline P19338 & NUCL_HUMAN & Nucleolin & 77 & 3 & 6 & 9 \\
\hline Q16787 & LAMA3_HUMAN & Laminin subunit alpha-3 & 367 & 3 & 3 & 3 \\
\hline P02462 & CO4A1_HUMAN & Collagen alpha-1(IV) chain & 161 & 3 & 2 & 5 \\
\hline P60903 & S10AA_HUMAN & Protein S100-A10 & 11 & 2 & 35 & 4 \\
\hline P62158 & CALM_HUMAN & Calmodulin & 17 & 2 & 26 & 5 \\
\hline P31949 & S10AB_HUMAN & Protein S100-A11 & 12 & 2 & 24 & 4 \\
\hline P62854 & RS26_HUMAN & 40S ribosomal protein S26 & 13 & 2 & 21 & 12 \\
\hline P62847 & RS24_HUMAN & 40S ribosomal protein S24 & 15 & 2 & 20 & 7 \\
\hline Q9NZZ3 & CHMP5_HUMAN & $\begin{array}{l}\text { Charged multivesicular body } \\
\text { protein } 5\end{array}$ & 25 & 2 & 18 & 2 \\
\hline P02538 & K2C6A_HUMAN & Keratin, type II cytoskeletal 6A & 60 & 2 & 13 & 25 \\
\hline P09972 & ALDOC_HUMAN & Fructose-bisphosphate aldolase C & 39 & 2 & 13 & 4 \\
\hline O75367 & H2AY_HUMAN & Core histone macro-H2A.1 & 40 & 2 & 12 & 6 \\
\hline P53999 & TCP4_HUMAN & $\begin{array}{l}\text { Activated RNA polymerase II } \\
\text { transcriptional coactivator } \mathrm{p} 15\end{array}$ & 14 & 2 & 12 & 4 \\
\hline P18124 & RL7_HUMAN & $60 \mathrm{~S}$ ribosomal protein $\mathrm{L} 7$ & 29 & 2 & 10 & 3 \\
\hline P08758 & ANXA5_HUMAN & Annexin A5 & 36 & 2 & 10 & 3 \\
\hline P19013 & K2C4_HUMAN & Keratin, type II cytoskeletal 4 & 57 & 2 & 8 & 13 \\
\hline P62424 & RL7A_HUMAN & $60 \mathrm{~S}$ ribosomal protein $\mathrm{L} 7 \mathrm{a}$ & 30 & 2 & 7 & 6 \\
\hline P08729 & K2C7_HUMAN & Keratin, type II cytoskeletal 7 & 51 & 2 & 7 & 11 \\
\hline P62195 & PRS8_HUMAN & $26 \mathrm{~S}$ protease regulatory subunit 8 & 46 & 2 & 7 & 2 \\
\hline P50454 & SERPH_HUMAN & Serpin H1 & 46 & 2 & 7 & 2 \\
\hline P51884 & LUM_HUMAN & Lumican & 38 & 2 & 7 & 4 \\
\hline Q7Z794 & K2C1B_HUMAN & Keratin, type II cytoskeletal 1b & 62 & 2 & 7 & 21 \\
\hline P15169 & CBPN_HUMAN & Carboxypeptidase $\mathrm{N}$ catalytic chain & 52 & 2 & 6 & 2 \\
\hline P26641 & EF1G_HUMAN & Elongation factor 1-gamma & 50 & 2 & 6 & 4 \\
\hline P02749 & APOH_HUMAN & Beta-2-glycoprotein 1 & 38 & 2 & 5 & 4 \\
\hline P30101 & PDIA3_HUMAN & Protein disulfide-isomerase A3 & 57 & 2 & 5 & 3 \\
\hline P21980 & TGM2_HUMAN & $\begin{array}{l}\text { Protein-glutamine } \\
\text { gamma-glutamyltransferase } 2\end{array}$ & 77 & 2 & 4 & 5 \\
\hline P49747 & COMP_HUMAN & Cartilage oligomeric matrix protein & 83 & 2 & 4 & 4 \\
\hline Q9H6S3 & ES8L2_HUMAN & $\begin{array}{l}\text { Epidermal growth factor receptor } \\
\text { kinase substrate } 8 \text {-like protein } 2\end{array}$ & 81 & 2 & 4 & 3 \\
\hline P23229 & ITA6_HUMAN & Integrin alpha-6 & 127 & 2 & 3 & 2 \\
\hline Q14112 & NID2_HUMAN & Nidogen-2 & 151 & 2 & 2 & 3 \\
\hline Q92954 & PRG4_HUMAN & Proteoglycan 4 & 151 & 2 & 2 & 10 \\
\hline P08123 & CO1A2_HUMAN & Collagen alpha-2(I) chain & 129 & 2 & 2 & 3 \\
\hline P01031 & CO5_HUMAN & Complement C5 & 188 & 2 & 1 & 3 \\
\hline P24821 & TENA_HUMAN & Tenascin & 241 & 2 & 1 & 2 \\
\hline P98160 & PGBM_HUMAN & $\begin{array}{l}\text { Basement membrane-specific } \\
\text { heparan sulfate proteoglycan } \\
\text { core protein }\end{array}$ & 469 & 2 & 0 & 3 \\
\hline
\end{tabular}


A

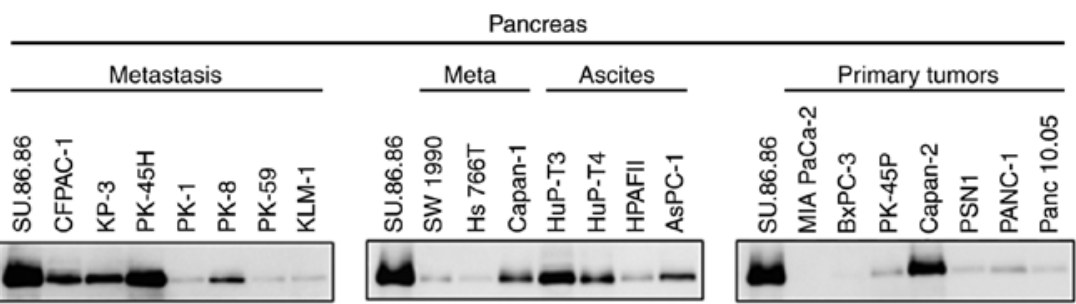

Exo

Eps8
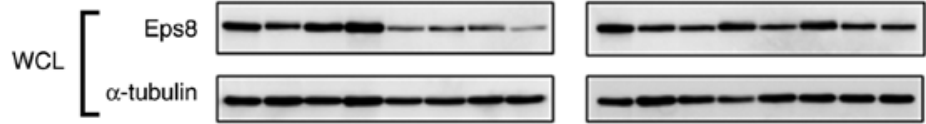

B

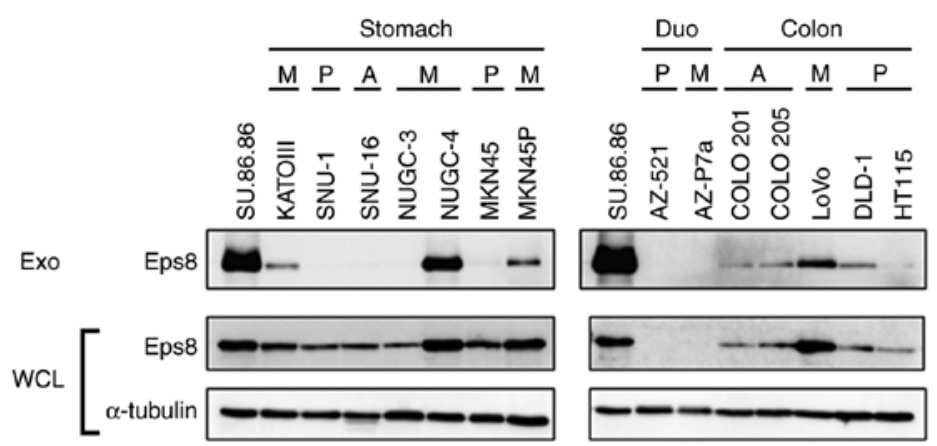

Figure 3. Exosomal and intracellular Eps8 protein levels in cancer cell lines. (A) Exosomal and intracellular Eps8 levels in pancreatic cancer cell lines derived from metastasis (Meta, M), ascites (A) and primary tumors (P). (B) Exosomal and intracellular Eps8 levels in cancer cell lines derived from stomach, duodenum and colon. Proteins $(5 \mathrm{mg}$ ) from WCL and exosomes Exo were separated by $8 \%$ SDS-PAGE followed by immunoblotting using a mouse monoclonal Eps8 antibody. $\alpha$-tubulin protein levels were measured as internal standards. ESP8, epidermal growth factor receptor pathway substrate 8; WLC, whole cell lysates; Exo, exosomes.

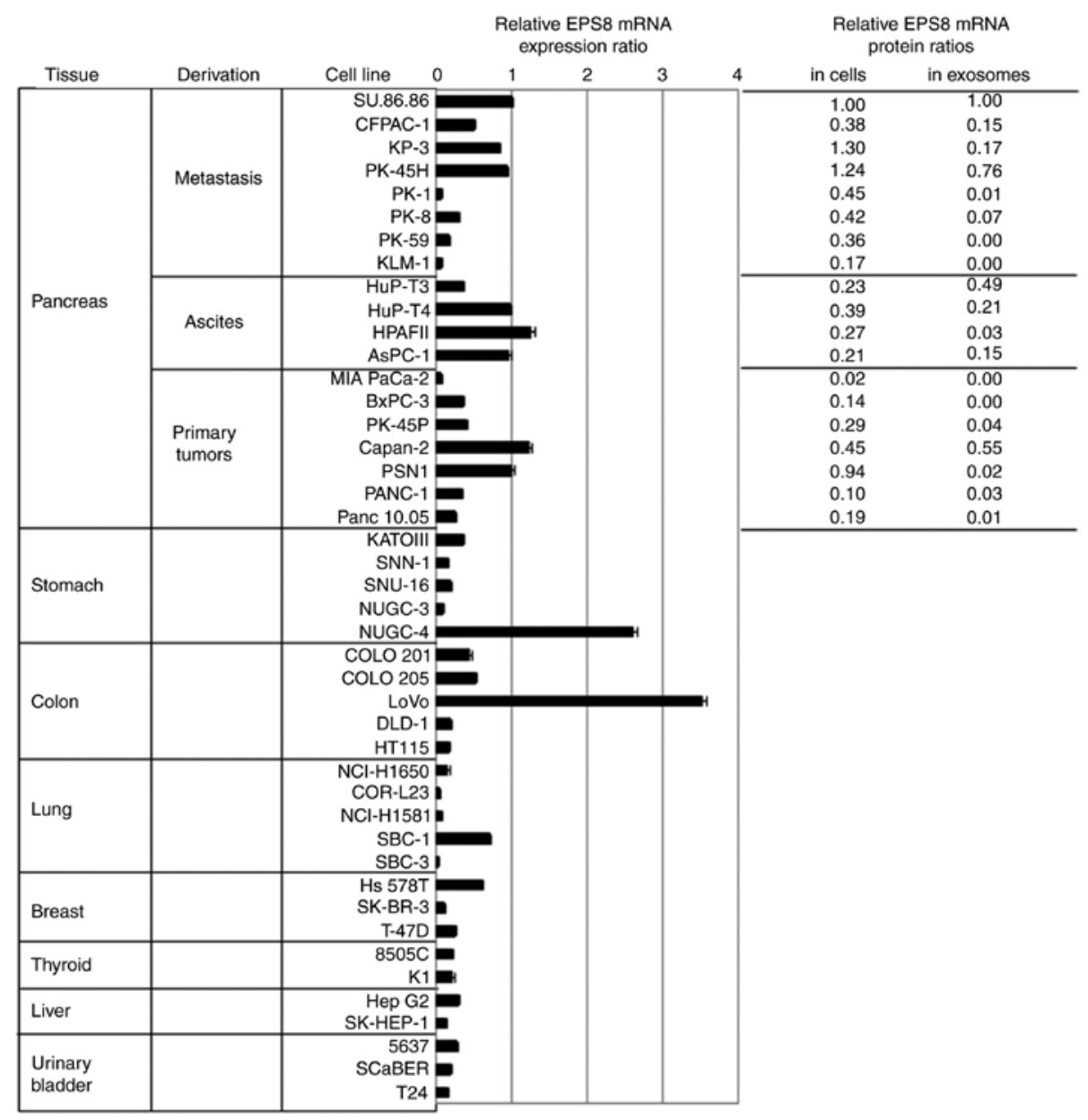

Figure 4. Intracellular EPS8 mRNA levels in cancer cell lines. EPS8 mRNA levels in cancer cell lines relative to the levels assessed in SU.86.86 cells are presented. Relative intracellular and exosomal Eps8 protein levels are presented on the right side. ESP8, epidermal growth factor receptor pathway substrate 8 . 
A
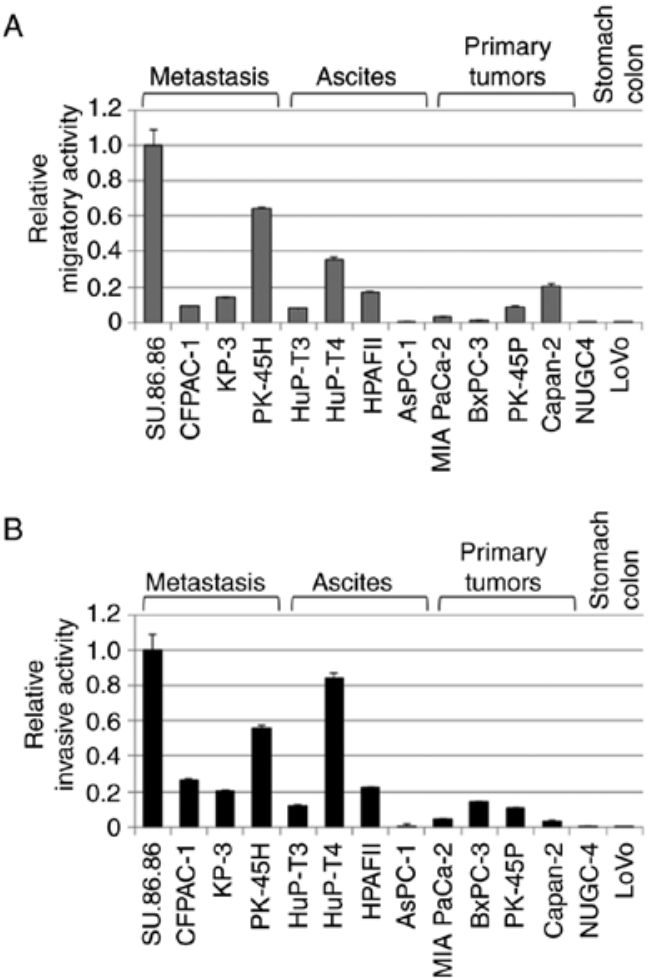

Figure 5. Cell migratory and invasive activities in pancreatic cancer cell lines. Relative activities of (A) cell migration and (B) invasion among cancer cell lines are presented relative to the activities observed in SU.86.86 cells NUGC-4 cells derived from stomach cancer and LoVo cells from colon cancer were examined as these cells exhibited moderate levels of exosomal Eps8 immunoreactivity. ESP8, epidermal growth factor receptor pathway substrate 8 .

and KP-3, respectively. In ascites-derived cell lines HuP-T3, HuP-T4, and AsPC-1, and the Capan-2 primary tumor cell line, the relative Eps8 immunoreactivity was $0.49,0.21,0.15$ and 0.55 , respectively. Intracellular Eps8 levels varied among the cell lines, particularly those derived from metastasis (PK-1, PK-8, PK-59 and KLM-1) and primary tumors (MIA PaCa-2, BxPC-3, PANC-1 and Panc 10.05). Except for PK-8, there was either no Eps8 immunoreactivity, or less Eps8 immunoreactivity, relative to that observed intracellularly, observed in the exosomes of these cells. Also, distinct Eps8 immunoreactivity was observed in NUGC-4 and MKN45P stomach cancer cell lines and the LoVo colon cancer cell line (Fig. 3B). Furthermore, cells with relatively high intracellular Eps8 protein levels expressed greater amounts of EPS8 mRNA (Fig. 4). However, Eps8 protein and mRNA expression levels did not correlate with the amount of Eps8 in exosomes. Collectively, these results revealed that, particularly in pancreatic cancer cells derived from metastasis and ascites, Eps8 was secreted into the extracellular environment via exosomes.

In vitro migratory and invasive activities of pancreatic cancer cell lines. It was revealed that Eps8 protein is present in the exosomes of several pancreatic cancer cell lines in addition to SU.86.86. Therefore, we evaluated the in vitro cell migratory and invasive activities in 12 pancreatic cancer cell lines. The highest levels of migratory and invasive activities were observed in SU.86.86 cells, and these were set at a value of 1 to allow for comparison (Fig. 5). The metastatic PK-45H cell line, with the relative exosomal Eps8 protein level of 0.76, revealed relatively high levels of cell migratory (0.64) and invasive activities (0.56). Additionally, in ascites-derived HuP-T4 cells, with the relative exosomal Eps8 protein level of 0.21 , relatively high levels of cell migratory $(0.36)$ and invasive activities $(0.84)$ were observed. However, no cell motility was detected in stomach cancer-derived NUGC-4 cells and colon cancer-derived LoVo cells, which exhibited moderate levels of exosomal Eps8 immunoreactivities (Fig. 3).

Integrative comparison of the data revealed that similar to SU.86.86 cells, PK-45H cells consistently had the highest levels of in vitro cell migratory and invasive activities, exosomal and intracellular Eps8 protein, and EPS8 mRNA expression (Fig. 6A and B). Furthermore, using the Pearson correlation coefficient, we identified that exosomal Eps8 levels were significantly correlated with migratory cell levels $\left(\mathrm{r}=0.85, \mathrm{P}=4.2 \times 10^{-4}\right)$ (Fig. 6C). Therefore, we proposed that exosomal Eps8 protein level is indicative of metastatic potential in human pancreatic cancer cells.

\section{Discussion}

The present study revealed abundant levels of Eps8 protein in exosomes derived from pancreatic cancer cell lines. Furthermore, it was revealed that exosomal Eps8 levels were significantly correlated with migratory cell potential (Fig. 6C). Eps8 was initially identified as a substrate for the epidermal growth factor (EGF) receptor that enhances EGF-dependent mitogenic signals $(23,24)$. Overexpression of Eps8 has been revealed to promote cellular proliferation and/or migration in various tumor types, including breast cancer (25), malignant glioma $(26,27)$, pituitary tumors (28), oral squamous cell carcinoma (29), and cervical cancer (30). In Eps8-mediated tumorigenesis and proliferation, stimulated EGFR results in the activation of downstream pathways, including Eps8/Ras/MAPK, Eps8/Akt/FoxM1 and Eps8/mTOR/STAT3 were revealed (31).

Eps8 expression was enhanced in pancreatic cancer at both protein and mRNA levels (22), and Eps8 upregulation was immunohistochemically detected in $72 \%$ of paraffin-embedded clinical specimens (32). Welsch et al demonstrated that Eps8 expression levels were correlated with the degree of malignancy in pancreatic cancer cell lines (22). They found low levels of Eps8 expression in cell lines from primary pancreatic cancers (MIAPaCa-2, BxPC-3, and PANC-1), moderate Eps8 expression levels in cell lines from metastasis (SU.86.86 and Capan-1), and high Eps8 expression level in a cell line from malignant ascites (AsPC-1) (22). Additionally, their Eps8 expression levels were positively correlated with migratory potential (BxPC-3 < PANC-1<Capan-1<AsPC-1). In the present study, a moderate correlation between cell migratory capacity and intracellular Eps8 protein expression levels $\left(\mathrm{r}=0.65, \mathrm{P}=2.0 \times 10^{-2}\right)$ was revealed but not between cell migratory capacity and intracellular EPS8 mRNA expression levels $\left(\mathrm{r}=0.44, \mathrm{P}=1.5 \times 10^{-1}\right.$ ) (Fig. 6C). However, we identified a significant correlation between exosomal Eps8 protein levels and migratory cell capacity $\left(\mathrm{r}=0.85, \mathrm{P}=4.2 \times 10^{-4}\right)$. The pancreatic cancer cell lines that exhibited relatively high exosomal Eps8 protein levels were SU.86.86 and PK-45H from metastasis, HuP-T3 from ascites, and Capan-2 from 
A
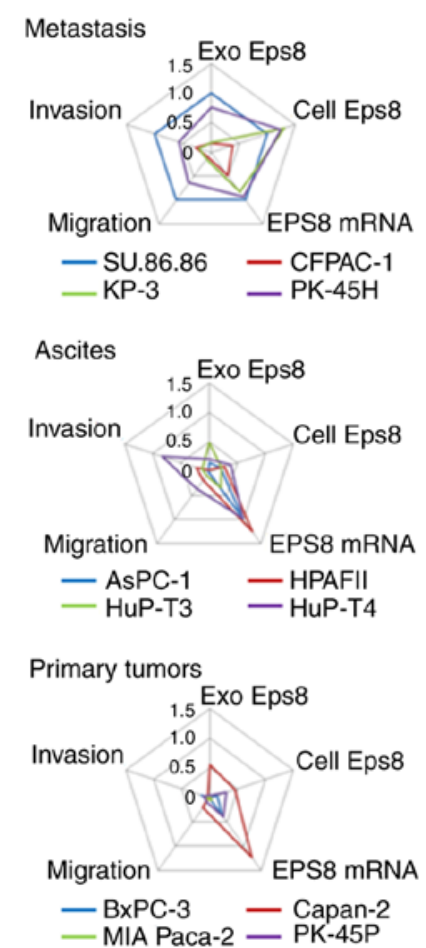

B

\begin{tabular}{|c|c|c|c|c|c|c|}
\hline & & \multicolumn{3}{|c|}{ Relative ratio of Eps8 } & \multicolumn{2}{|c|}{ Relative ratio } \\
\hline & & $\begin{array}{l}\text { Protein } \\
\text { in Exo }\end{array}$ & $\begin{array}{l}\text { Protein } \\
\text { in cells }\end{array}$ & $\begin{array}{l}\text { mRNA } \\
\text { in cells }\end{array}$ & Migration & Invasion \\
\hline \multirow[t]{4}{*}{ Metastasis } & SU.86.86 & 1.00 & 1.00 & 1.00 & 1.00 & 1.00 \\
\hline & CFPAC-1 & 0.15 & 0.38 & 0.49 & 0.09 & 0.27 \\
\hline & KP-3 & 0.17 & 1.30 & 0.84 & 0.14 & 0.21 \\
\hline & $\mathrm{PK}-45 \mathrm{H}$ & 0.76 & 1.24 & 0.94 & 0.64 & 0.56 \\
\hline \multirow[t]{4}{*}{ Ascites } & AsPC-1 & 0.15 & 0.21 & 0.96 & 0.01 & 0.01 \\
\hline & HPAFII & 0.03 & 0.27 & 1.26 & 0.17 & 0.23 \\
\hline & HuP-T3 & 0.49 & 0.23 & 0.34 & 0.08 & 0.12 \\
\hline & HuP-T4 & 0.21 & 0.39 & 0.97 & 0.36 & 0.84 \\
\hline \multirow[t]{4}{*}{ Primary tumors } & BxPC-3 & NA & 0.14 & 0.35 & 0.01 & 0.14 \\
\hline & Capan-2 & 0.55 & 0.45 & 1.23 & 0.20 & 0.04 \\
\hline & MIA PaCa-2 & NA & 0.02 & 0.05 & 0.03 & 0.05 \\
\hline & $\mathrm{PK}-45 \mathrm{P}$ & 0.04 & 0.29 & 0.40 & 0.09 & 0.11 \\
\hline
\end{tabular}

C

\begin{tabular}{|c|c|c|c|c|c|}
\hline & Exo Eps8 & Cell Eps8 & Eps8 mRNA & Migration & Invasion \\
\hline Exo Eps8 & 1 & $\begin{array}{c}0.61 \\
3.6 \times 10^{-2}\end{array}$ & $\begin{array}{c}0.40 \\
2.0 \times 10^{-1}\end{array}$ & $\begin{array}{c}0.85 \\
4.2 \times 10^{-4}\end{array}$ & $\begin{array}{c}0.60 \\
3.7 \times 10^{-2}\end{array}$ \\
\hline Cell Eps8 & $\begin{array}{c}0.61 \\
3.6 \times 10^{-2} \\
\end{array}$ & 1 & $\begin{array}{c}0.43 \\
1.6 \times 10^{-1} \\
\end{array}$ & $\begin{array}{c}0.65 \\
2.0 \times 10^{-2} \\
\end{array}$ & $\begin{array}{c}0.51 \\
9.2 \times 10^{-2} \\
\end{array}$ \\
\hline Eps8 mRNA & $\begin{array}{c}0.40 \\
2.0 \times 10^{-1}\end{array}$ & $\begin{array}{c}0.43 \\
1.6 \times 10^{-1}\end{array}$ & 1 & $\begin{array}{c}0.44 \\
1.5 \times 10^{-1}\end{array}$ & $\begin{array}{c}0.35 \\
2.6 \times 10^{-1}\end{array}$ \\
\hline Migration & $\begin{array}{c}0.85 \\
4.2 \times 10^{-4}\end{array}$ & $\begin{array}{c}0.65 \\
2.0 \times 10^{-2}\end{array}$ & $\begin{array}{c}0.44 \\
1.5 \times 10^{-1}\end{array}$ & 1 & $\begin{array}{c}0.87 \\
2.0 \times 10^{-4}\end{array}$ \\
\hline Invasion & $\begin{array}{c}0.60 \\
3.7 \times 10^{-2}\end{array}$ & $\begin{array}{c}0.51 \\
9.2 \times 10^{-2}\end{array}$ & $\begin{array}{c}0.35 \\
2.6 \times 10^{-1}\end{array}$ & $\begin{array}{c}0.87 \\
2.0 \times 10^{-4}\end{array}$ & 1 \\
\hline
\end{tabular}

Figure 6. Comparison of Eps8 levels in the exosomes and cells of pancreatic cancer cell lines. The cell motile activities of cell lines derived from metastasis, ascites, and primary tumors were compared. (A) Radar charts revealing relative Eps8 protein in exosomes and cells, Eps8 mRNA expression level, and cell migratory and invasive activities. (B) Relative Eps8 protein and mRNA levels and cell motility in pancreatic cancer cells and their exosomes. (C) Correlations between exosomal Eps8 protein level, intracellular Eps8 protein and mRNA levels, and cell migratory and invasive activities. Correlation coefficient $r$ and P-values are represented by the upper and lower numbers in each cell. ESP8, epidermal growth factor receptor pathway substrate 8.

primary tumor cells (Figs. 3A and 6B). Despite originating from primary tumor cells, Capan-2 exhibited moderate cell migratory activity (Figs. 5A and 6B). These results were consistent with those revealing that Capan-2 possessed metastatic potential to the liver after being inoculated into nude mice (33). AsPC-1 cells, derived from ascites, have been previously revealed to have intracellular Eps8 protein and mRNA expression levels and migratory cell potential greater than those of metastasis-derived SU.86.86 cells (22). In our study, AsPC-1 cells had lower levels of intracellular and exosomal Eps8 protein and migratory cell levels than did SU.86.86 cells (Figs. 3A, 5A and 6B). We assume that these different results for AsPC-1 cells are at least due to culture conditions for maintenance of the cell line and preparation of samples. Additionally, among three groups of pancreatic cancer cell lines with different degrees of malignancy, intracellular Eps8 expression levels were significantly higher in cells from metastasis than in those from ascites $(\mathrm{P}=0.01628$, the Bonferroni-corrected threshold for multiple t-tests $=0.01667, \alpha=0.05)$. Eps8 expression in ascites-derived cell lines did not significantly differ from that of primary tumor-derived cell lines $(\mathrm{P}=0.634)$. Eps8 expression levels in metastasis-derived cell lines were significantly higher than in primary tumor-derived cell lines $(\mathrm{P}=0.01662)$. We compared the levels of exosomal Eps8 protein, intracellular Eps8 mRNA, migratory and invasive activities of metastasis-, ascites-, and primary tumor-derived cell line groups and found no significant differences. Therefore, the present study indicated that there is a strong relationship between exosomal Eps8 protein level and migratory cell potential.

Exosomes play an essential role in tumor metastasis (34). Eps8 is involved in metastasis, and inhibiting Eps8 expression results in decreased levels of cell motility $(26,30,32)$. The Eps8 protein localizes to lysosomes via the late endosomes, which function as a pre-degenerative compartment (35). The late endosomes also function as a recycling compartment, leading to extracellular secretion via fusion with the plasma membrane $(1,36,37)$. Collectively, with the present results, it may be inferred that Eps8 protein is recruited to late endosomes, leading to either inclusion in lysosomes or extracellular secretion. Our results revealed that in pancreatic cancer cell lines with high migratory potential, Eps8 protein abundance in exosomes occurs through extracellular secretion. These observations indicated that exosomal Eps8 has a potential to be a metastatic biomarker for pancreatic cancer. Further studies need to be performed using clinical samples to validate this hypothesis. For validation, it is conceivable to use an ELISA system, which can easily detect secreted proteins in serum or plasma blood samples. For proteins embedded in exosomes, such as Eps8, it is challenging to develop an ELISA system, since detergents that may affect the assay are used for exosome lysis during the sample preparation.

\section{Acknowledgements}

Not applicable. 


\section{Funding}

The present study was supported by the JSPS KAKENHI grant nos. JP26430150 and JP16K10523 to K.O.

\section{Availability of data and materials}

The datasets used during the present study are available from the corresponding author upon reasonable request.

\section{Authors' contributions}

KO made substantial contributions to the design of the study, drafting of the manuscript, cell culture and the preparation of the exosomes. KH, KWN and NS were responsible for the proteome analysis using LC-MS/MS. KK and TI performed the western blotting experiments. KK, YW and SM were involved in RNA preparation and RT-PCR analysis. KY and TM supervised the study and analyzed the data. All authors read and approved the manuscript and agree to be accountable for all aspects of the research in ensuring that the accuracy or integrity of any part of the work are appropriately investigated and resolved.

\section{Ethics approval and consent to participate}

This article contains no studies with human participants performed by any of the authors.

\section{Patient consent for publication}

Not applicable.

\section{Competing interests}

The authors declare that they have no competing interests.

\section{References}

1. Colombo M, Raposo G and Théry C: Biogenesis, secretion, and intercellular interactions of exosomes and other extracellular vesicles. Annu Rev Cell Dev Biol 30: 255-289, 2014.

2. Greening DW, Xu R, Gopal SK, Rai A and Simpson RJ: Proteomic insights into extracellular vesicle biology-defining exosomes and shed microvesicles. Expert Rev Proteomics 14: 69-95, 2007.

3. Kalluri R: The biology and function of exosomes in cancer. J Clin Invest 126: 1208-1215, 2016.

4. Soung YH, Ford S, Zhang V and Chung J: Exosomes in cancer diagnostics. Cancers 9: 8, 2017.

5. Choi DS, Kim DK, Kim YK and Gho YS: Proteomics, transcriptomics and lipidomics of exosomes and ectosomes. Proteomics 13: 1554-1571, 2013.

6. EL Andaloussi S, Mäger I, Breakefield XO and Wood MJ: Extracellular vesicles: Biology and emerging therapeutic opportunities. Nat Rev Drug Discov 12: 347-357, 2013.

7. Siegel RL, Miller KD and Jemal A: Cancer statistics, 2017. CA Cancer J Clin 67: 7-30, 2017.

8. Ferlay J, Partensky C and Bray F: More deaths from pancreatic cancer than breast cancer in the EU by 2017. Acta Oncol 55 1158-1160, 2016.

9. Hanada K, Okazaki A, Hirano N, Izumi Y, Teraoka Y, Ikemoto J, Kanemitsu K, Hino F, Fukuda T and Yonehara S: Diagnostic strategies for early pancreatic cancer. J Gastroenterol 50: $147-154,2015$.

10. Nuzhat Z, Kinhal V, Sharma S, Rice GE, Joshi V and Salomon C: Tumour-derived exosomes as a signature of pancreatic cancer-liquid biopsies as indicators of tumour progression. Oncotarget 8: 17279-17291, 2017.
11. Le Large TYS, Bijlsma MF, Kazemier G, van Laarhoven HWM, Giovannetti E and Jimenez CR: Key biological processes driving metastatic spread of pancreatic cancer as identified by multi-omics studies. Semin Cancer Biol 44: 153-169, 2017.

12. Sasaki K, Sato K, Akiyama Y, Yanagihara K, Oka M and Yamaguchi K: Peptidomics-based approach reveals the secretion of the 29-residue COOH-terminal fragment of the putative tumor suppressor protein DMBT1 from pancreatic adenocarcinoma cell lines. Cancer Res 62: 4894-4898, 2002.

13. Ogura S, Kaneko K, Miyajima S, Ohshima K, Yamaguchi K and Mochizuki T: Proneurotensin/neuromedin N secreted from small cell lung carcinoma cell lines as a potential tumor marker. Proteomics Clin Appl 2: 1620-1627, 2008.

14. Valadi H, Ekström K, Bossios A, Sjöstrand M, Lee JJ and Lötvall JO: Exosome-mediated transfer of mRNAs and microRNAs is a novel mechanism of genetic exchange between cells. Nat Cell Biol 9: 654-659, 2007.

15. Ohshima K, Kanto K, Hatakeyama K, Ide T, WakabayashiNakao K, Watanabe Y, Sakura N, Terashima M, Yamaguchi K and Mochizuki T: Exosome-mediated extracellular release of polyadenylate-binding protein 1 in human metastatic duodenal cancer cells. Proteomics 14: 2297-2306, 2014.

16. Ohshima K, Inoue K, Fujiwara A, Hatakeyama K, Kanto K, Watanabe Y, Muramatsu K, Fukuda Y, Ogura S, Yamaguchi K and Mochizuki T: Let-7 microRNA family is selectively secreted into the extracellular environment via exosomes in a metastatic gastric cancer cell line. PLoS One 5: e13247, 2010.

17. Hatakeyama K, Ohshima K, Fukuda Y, Ogura S, Terashima M, Yamaguchi K and Mochizuki T: Identification of a novel protein isoform derived from cancer-related splicing variants using combined analysis of transcriptome and proteome. Proteomics 11: 2275-2282, 2011.

18. Livak KJ and Schmittgen TD: Analysis of relative gene expression data using real-time quantitative PCR and the $2^{-\Delta \Delta C \mathrm{~T}}$ method. Methods 25: 402-408, 2001.

19. Drucker BJ, Marincola FM, Siao DY, Donlon TA, Bangs CD and Holder WD Jr: A new human pancreatic carcinoma cell line developed for adoptive immunotherapy studies with lymphokine-activated killer cells in nude mice. In Vitro Cell Dev Biol 24: 1179-1187, 1988.

20. Yunis AA, Arimura GK and Russin DJ: Human pancreatic carcinoma (MIA PaCa-2) in continuous culture: Sensitivity to asparaginase. Int J Cancer 19: 128-135, 1977.

21. Limame R, Wouters A, Pauwels B, Fransen E, Peeters M, Lardon F, De Wever O and Pauwels P: Comparative analysis of dynamic cell viability, migration and invasion assessments by novel real-time technology and classic endpoint assays. PLoS One 7: e46536, 2012.

22. Welsch T, Endlich K, Giese T, Büchler MW and Schmidt J: Eps8 is increased in pancreatic cancer and required for dynamic actin-based cell protrusions and intercellular cytoskeletal organization. Cancer Lett 255: 205-218, 2007.

23. Fazioli F, Minichiello L, Matoska V, Castagnino P, Miki T, Wong WT and Di Fiore PP: Eps8, a substrate for the epidermal growth factor receptor kinase, enhances EGF-dependent mitogenic signals. EMBO J 12: 3799-3808, 1993.

24. Castagnino P, Biesova Z, Wong WT, Fazioli F, Gill GN and Di Fiore PP: Direct binding of eps8 to the juxtamembrane domain of EGFR is phosphotyrosine- and $\mathrm{SH} 2$-independent. Oncogene 10: 723-729, 1995.

25. Chen C, Liang Z, Huang W, Li X, Zhou F, Hu X, Han M, Ding X and Xiang S: Eps8 regulates cellular proliferation and migration of breast cancer. Int J Oncol 46: 205-214, 2015.

26. Cattaneo MG, Cappellini E and Vicentini LM: Silencing of Eps8 blocks migration and invasion in human glioblastoma cell lines. Exp Cell Res 318: 1901-1912, 2012.

27. Ding X, Zhou F, Wang F, Yang Z, Zhou C, Zhou J, Zhang B, Yang J, Wang G, Wei Z, et al: Eps8 promotes cellular growth of human malignant gliomas. Oncol Rep 29: 697-703, 2013.

28. Xu M, Shorts-Cary L, Knox AJ, Kleinsmidt-DeMasters B, Lillehei K and Wierman ME: Epidermal growth factor receptor pathway substrate 8 is overexpressed in human pituitary tumors: Role in proliferation and survival. Endocrinology 150: 2064-2071, 2009.

29. Yap LF, Jenei V, Robinson CM, Moutasim K, Benn TM, Threadgold SP, Lopes V, Wei W, Thomas GJ and Paterson IC: Upregulation of Eps8 in oral squamous cell carcinoma promotes cell migration and invasion through integrin-dependent Rac1 activation. Oncogene 28: 2524-2534, 2009. 
30. Li Q, Bao W, Fan Q, Shi WJ, Li ZN, Xu Y and Wu D: Epidermal growth factor receptor kinase substrate 8 promotes the metastasis of cervical cancer via the epithelial-mesenchymal transition. Mol Med Rep 14: 3220-3228, 2016.

31. Li YH, Xue TY, He YZ and Du JW: Novel oncoprotein EPS8: A new target for anticancer therapy. Future Oncol 9: 1587-1594, 2013.

32. Tod J, Hanley CJ, Morgan MR, Rucka M, Mellows T, Lopez MA, Kiely P,Moutasim KA, Frampton SJ, Sabnis D, et al: Pro-migratory and TGF- $\beta$-activating functions of $\alpha v \beta 6$ integrin in pancreatic cancer are differentially regulated via an Eps8-dependent GTPase switch. J Pathol 243: 37-50, 2017.

33. Uchima Y, Sawada T, Nishihara T, Maeda K, Ohira M and Hirakawa K: Inhibition and mechanism of action of a protease inhibitor in human pancreatic cancer cells. Pancreas 29: 123-131, 2004.

34. Peinado H, Zhang H, Matei IR, Costa-Silva B, Hoshino A, Rodrigues G, Psaila B, Kaplan RN, Bromberg JF, Kang Y, et al: Pre-metastatic niches: Organ-specific homes for metastases. Nat Rev Cancer 17: 302-317, 2017.
35. Welsch T, Younsi A, Disanza A, Rodriguez JA, Cuervo AM, Scita $\mathrm{G}$ and Schmidt J: Eps8 is recruited to lysosomes and subjected to chaperone-mediated autophagy in cancer cells. Exp Cell Res 316: 1914-1924, 2010.

36. Théry C, Zitvogel L and Amigorena S: Exosomes: Composition, biogenesis and function. Nat Rev Immunol 2: 569-579, 2002.

37. Théry C, Ostrowski M and Segura E: Membrane vesicles as conveyors of immune responses. Nat Rev Immunol 9: 581-593, 2009.

38. Yonemura Y, Endo Y, Yamaguchi T, Fujimura T, Obata T, Kawamura T, Nojima N, Miyazaki I and Sasaki T: Mechanisms of the formation of the peritoneal dissemination in gastric cancer. Int J Oncol 8: 795-802, 1996.

39. Nishimori H, Yasoshima T, Denno R, Shishido T, Hata F, Okada Y, Ura H, Yamaguchi K, Isomura H, Sato N, et al: A novel experimental mouse model of peritoneal dissemination of human gastric cancer cells: Different mechanisms in peritoneal dissemination and hematogenous metastasis. Jpn J Cancer Res 91: 715-722, 2000.

40. López-Terrada D, Cheung SW, Finegold MJ and Knowles BB: Hep G2 is a hepatoblastoma-derived cell line. Hum Pathol 40: $1512-1515,2009$. 